\title{
REPRESENTASI BIBLIOTERAPI DALAM SERIAL TELEVISI WHEN CALLS THE HEART
}

\author{
Maya Pradhipta Hapsari \\ UPT Perpustakaan Universitas Jember \\ maya.library@unej.ac.id
}

\begin{abstract}
ABSTRAK
Penelitian ini bertujuan untuk mengetahui representasi biblioterapi dalam serial televisi When Calls The Heart sebagai sarana pembelajaran karena televisi merupakan media yang sangat berpengaruh dalam penyebaran nilai-nilai dalam masyarakat termasuk literasi dan budaya baca. Representasi ini mencakup tahapan- tahapan yang terdiri dari kesiapan, seleksi buku, memperkenalkan buku, dan strategi tindak lanjut yang ditambah dengan hasil yang dicapai dari biblioterapi. Penelitian ini merupakan penelitian kualitatif menggunakan metode analisis semiotika dengan unit analisis teks-teks berupa narasidan gambar dalam satu episode When Calls The Heart yang ditetapkan sebagai objek penelitian, yang berkaitan dengan praktik biblioterapi. Hasil penelitian ini adalah bahwa dalam serial televisi When Calls The Heart, bibliografi direpresentasikan dalam adegan-adegan antara guru yang bertindak sebagai terapis dengan muridnya yang bermasalah sebagai klien mulai dari kesiapan hingga strategi tindak lanjut hingga akhirnya memperoleh hasil yang diharapkan dari tujuan biblioterapi.
\end{abstract}

Kata Kunci: representasi, biblioterapi, serial televisi, When Calls The Heart.

\section{PENDAHULUAN}

Saat ini orangtua dan tenaga pendidik serta kependidikan termasuk pustakawan dihadapkan pada kecermatan dalam penyediaan dan pemanfaatan sumber-sumber informasi yang dibutuhkan dalam kegiatan pendidikan. Apalagi dengan adanya gerakan literasi yang dicetuskan oleh pemerintah yang sudah dimulai oleh banyak lembaga pendidikan baik tingkat dasar maupun pendidikan tinggi. Meskipun teknologi amat berperan terutama karena pemustaka generasi sekarang cenderung lebih menyukai sesuatu yang serba cepat dan praktis,namun teknologi juga memiliki kelemahan. Terutama di era keterbukaan informasi yang memudahkan siapa pun mengakses apa pun, justru penggunaan gawai pada anak harus dibatasi untuk lebih memberi kesempatan orang tua dan pendidik mencukupi kebutuhan mendasar anak terlebih dahulu yaitu kebutuhan spiritual-agama, sosial-emosional, dan psikomotorik (Agustina, 2017:128). Dan dalam hal ini, yang menjadi perhatian para pendidik, orangtua serta pustakawan tetap ada pada buku tercetak sebagai media yang dapat diandalkan.

Buku dengan bentuknya yang sedemikian rupa masih dirasa lebih efektif. Dan dalam tingkatan pendidikan paling awal sebelum anak memasuki usia sekolah, memang dianjurkan bagi orangtua untuk membiasakan membacakan buku bagi mereka atau dikenal dengan istilah 'berkisah', yaitu menceritakan kisah-kisah yang bersumber dari buku. Kegiatan 
berkisah termasuk dalam wacana pemerintah yang dituangkan dalam Gerakan Nasional Orangtua Membacakan Buku (GERNASBAKU) oleh Kementerian Pendidikan dan Kebudayaan dalam rangka meningkatkan partisipasi keluarga dan lembaga pendidikan untuk menumbuhkan budaya membaca. ${ }^{1}$ Berkisah itu sendiri merupakan salah satu metode dalam biblioterapi yang juga adalah semacam softskill yang berfungsi sebagai pembimbing pembaca. Sedangkan istilah biblioterapi sendiri disepakati mengacu pada terapi buku dan terapi membaca atau juga terapi kisah (Agustina, 2017:51).

GERNASBAKU dapat memberi pemahaman bahwa buku memiliki banyak manfaat di antaranya adalah dengan membaca buku, anak siap menghadapi kehidupan nyata. Bisa saja cerita yang kita bacakan belum pernah mereka alami, namun cepat atau lambat mereka akan merasakannya. Ketika tiba saatnya, mereka telah mengalami gambaran pikiran dari cerita yang pernah dibacakan tersebut. Ini membuat anak secara mental lebih siap menghadapi kehidupan dunia nyata sesungguhnya (Widyastuti, 2017:10).

Segala usahapeningkatan minat baca yang telah dilakukan baik oleh pemerintah melalui kementerian yang terkait maupun LSM, diharapkan mampu memotivasi masyarakat terutama anak-anak untuk membaca dan perpustakaan menjadi lebih ramai. Kita tahu bahwa rendahnya minat baca anak disebabkan banyak faktor di antaranya yang bersifat institusional yang meliputi tersedianya bahan bacaan yang sesuai, latar belakang, status sosial dan ekonomi, kelompok etnis dan pengaruh teman sebaya, orang tua, guru, televisi serta film (Damaiwati, 2009:29).

Faktor lain yang juga dianggap memengaruhi minat baca adalah kultur. Budaya lisan berakar sangat kuat, demikian pula dengan dongeng-dongeng yang berkembang dengan baik di negara kita sehingga timbul anggapan bahwa kebiasaan membaca dianggap kurang penting. Padahal ilmu pengetahuan tidak cukup dapat dikuasai hanya dengan mendengar tetapi melalui proses membaca. Seharusnya kultur seperti ini bisa menjadi kekuatan jika bercerita dilakukan dengan menggunakan buku sebagai media berkisah. Buku merupakan media yang praktis digunakan dan praktik terapi buku sangat efektif dikenalkan melalui metode berkisah atau bercerita (Agustina, 2017:52).

Selain faktor-faktor yang disebut di atas, pengaruh hiburan seperti televisi dan filmjugadapat berkaitan dengan minat baca. Di sinilah peran orang tua amat diperlukan. Karena sebenarnya acara televisi juga bisa menjadi bahan pembelajaran bila kita menyeleksinya. Karena pembatasan menonton televisi belum tentu membawa hasil yang baik. Dalam beberapa kasus, anak-anak tampaknya tidak keberatan dan akhirnya menjadi pembaca yang baik tetapi dalam kasus-kasus lainnya, upaya membatasi televisi menyebabkan anak-anak marah, malah membuat mereka bosan membaca, dan hanya mendorong mereka untuk melanggar peraturan (Leonhardt, 1997:98). Bila kita mencermati film-film dan serial televisi produksi luar negeri (kita bisa memperolehnya dengan membeli DVD, berlangganan layanan streaming, TV kabel, atau mengunduhnya secara gratis), banyak di antaranya yang memperlihatkan adegan mengenai kebiasaan membaca. Seperti karakter tokoh utama yang gemar membaca, pekerjaan sehari-hari sebagai pemilik toko buku, pustakawan, maupun guru yang selalu menerapkan aktivitas literasi dalam metode mengajarnya, sementara di Indonesia

\footnotetext{
${ }^{1}$ http://gln.kemdikbud.go.id/glnsite/wp-content/uploads/2018/04/gom_booklet2018.pdf
} 
jarang sekali. Dalam hal ini Gol A. Gong, seorang pegiat literasi, mencermatinya dengan membayangkan presiden mengeluarkan surat keputusan yang mengharuskan semua produsen film memasukkan unsur-unsur budaya membaca ke dalam setiap film atau sinetronnya, misalnya melalui karakter para tokoh atau latarnya. Misinya adalah memproduksi film dan program televisi yang "beraromakan” budaya membaca. Di film You've Got Mail, Meg Ryan berperan sebagai penjaga toko buku. Yang luar biasa adalah adanya tradisi bercerita (storytelling) yang membuat film ini memiliki "roh" (Gong, 2012:26).

Di antara sekian banyak serial televisi yang tengah populer di Amerika saat ini, When Calls The Heart termasuk yang mengandung pesan literasi salah satunya adalah representasi praktik biblioterapi. Literasi sendiri secara tradisional dipandang sebagai kemampuan membaca dan menulis. Pengertian literasi selanjutnya berkembang menjadi kemampuan membaca, menulis, berbicara, dan menyimak (Widyastuti, 2017:xiv). Dalam perkembangan selanjutnya, definisi literasi telah bergeser karena penggunaannya yang menjadi lebih luas serta mengikuti perkembangan teknologi dan informasi.

When Calls The Heart merupakan serial televisi yang diadaptasi dari novel berseri Canadian West Series karangan Janette Oke, penulis berkebangsaan Kanada kelahiran 18 Februari 1935. Serial yang berlatar awal abad 20 di sebuah kota fiktif di Kanada bernama Coal Valley yang akhirnya berubah menjadi Hope Valleydengan tokoh utama Elizabeth Thornton, seorang guru ini ditayangkan oleh Hallmark Channel sejak 11 Januari 2014, dan tayangan terakhirnya adalah musim ke-6 episode 9 pada 2 Juni 2019. Season finale tersebut tercatat menduduki peringkat kedua dengan jumlah penonton terbanyak, sementara peringkat pertamanya adalah The Walking Dead (AMC Networks). ${ }^{2}$ Rating ini merupakan yang tertinggi sejak tayangan musim pertama. Karena ratingnya yang cukup tinggi tersebut, ditambah dengan banyaknya penggemar setia terutama kaum perempuan yang menamakan diri mereka "Hearties", serial ini akan dilanjutkan ke musim ke-7 pada 2020. Serial ini, seperti ciri khas film televisi produksi Hallmark, cukup banyak menggambarkan aktivitas literasi dalam metode pembelajaran yang diterapkan oleh sang tokoh utama Elizabeth Thornton terhadap murid-muridnya, termasuk biblioterapi.

Biblioterapi dapat disebut sebagai bagian dari rangkaian kesatuan layanan perpustakaan. Bahkan dapat dikatakan bahwa biblioterapi merupakan pendekatan jangka panjang untuk layanan perpustakaan dengan tujuan terapeutik (Monroe, dalam Agustina, 2017:52). Selama berabad-abad buku telah digunakan sebagai sumberdaya untuk membantu orang mengatasi masalahnya. Bahkan, praktik biblioterapi dapat ditelusuri hingga zaman Mesir kuno yang digunakan sebagai sumber bantuan untuk pengajaran dan penyembuhan (Schrank dan Engels, dalam Herlina, 2013:81). Mengingat pentingnya biblioterapi dalam peningkatan minat baca dan mengatasi permasalahan anak, maka pihak-pihak yang terlibat (termasuk guru, pustakawan, dan orang tua) perlu mengetahuinya. Selain dengan membaca sumber-sumber dari buku dan internet, media yang menyenangkan seperti serial televisi juga patut dipertimbangkan.

\footnotetext{
${ }^{2} \mathrm{http}: / / w w w . t h e f u t o n c r i t i c . c o m / r a t i n g s / 2019 / 06 / 07 /$ hallmark-channels-when-calls-the-heart-wraps-up- seasonsix-as-number-2-scripted-series-on-cable-243210/20190607hallmark01/

${ }^{3} \mathrm{http}: / /$ www.heartieswcth.com/
} 


\section{TINJAUAN PUSTAKA}

\section{Membaca dan Literasi}

Literasi sering dimaknai sebagai kemahirwacanaan yang fokus utamanya adalah pada kemampuan berpikir/bernalar kritis (Priyatni dan Nurhadi, 2017:157), sehingga dapat disimpulkan bahwa literasi berkaitan dengan pemaknaan teks dan konteksnya dengan menggunakan keterampilan berpikir tingkat tinggi untuk dimanfaatkan dalam memahami kehidupan dan berbagai aspeknya. Teks tersebut dapat berupa teks tulis, lisan (audio), visual, auditori, audiovisual, spasial, dan nonverbal.

Salah satu inti kemampuan literasi adalah kemampuan komunikasi dan representasi. Kemampuan komunikasi adalah kemampuan menyampaikan ide kepada orang lain sedangkan kemampuan representasi adalah kemampuan memformulasikan ide agar ide-ide yang disampaikan bermakna bagi orang lain. Kemampuan komunikasi dan representasi ini membutuhkan kemampuan berpikir dan bernalar yang merupakan hakikat dari membaca (Priyatni dan Nurhadi, 2017:14). Kegiatan berpikir dan bernalar dalam membaca ditandai oleh:

1. Keterlibatan personal dalam menyerap kedalaman informasi yang terdapat dalam teks

2. Pemikiran kritis yang ditandai oleh adanya kegiatan mental dalam menghubungkan hal-hal yang ada dalam teks dengan pengetahuan dan pengalaman yang dimiliki pembaca, mengaitkan informasi yang ada dalam teks dengan sesuatu di luar teks yang dianggap relevan dan eksplorasi untuk mendapatkan pemahaman yang utuh terhadap teks yang dibaca

3. Reaksi dan respon terhadap teks yang dibaca

Reaksi dan respon merupakan buah pemikiran dan penalaran terhadap teks yang dibaca. Bentuk dan kualitas respon ini sangat bergantung pada kompetensi pembaca. Hal inilah yang menjadi salah satu prinsip biblioterapi, yaitu kemampuan membaca klien harus diketahui dan dijadikan pengarah dalam memilih material bacaan yang akan digunakan (Herlina, 2013:94).

Membaca sebagai proses sosial mempersyaratkan adanya pengenalan, pengkajian, dan interaksi penulis-pembaca dan sekaligus hubungan sosial yang tercipta antara pihak yang terlibat dalam proses membaca (Bloome, dalam Priyatni dan Nurhadi, 2017:160). Dalam biblioterapi, pihak-pihak yang terlibat adalah terapis dan klien.

\section{Biblioterapi}

Istilah biblioterapi mengacu pada terapi buku dan terapi membaca, atau juga terapi kisah (Agustina, 2017:51). Istilah ini terbentuk dari kata biblio yang berasal dari bahasa Yunani biblus (buku) dan terapi, yang merujuk pada bantuan psikologis. Secara sederhana, biblioterapi didefinisikan sebagai penggunaan buku untuk membantu orang mengatasi masalahnya. Biblioterapi merupakan teknik menggunakan buku sebagai treatment (Herlina, 2013:77). Dalam layanan perpustakaan, biblioterapi memiliki kesamaan fungsi dengan referensi dan bimbingan membaca, di mana semuanya merupakan layanan yang bersifat informasi, instruksional, dan/atau kebutuhan bimbingan.

Biblioterapi merupakan pendampingan terbaik bagi permasalahan perilaku pada individu baik anak maupun dewasa. Salah satu metode yang digunakan dalam biblioterapi 
adalah berkisah. Buku dianggap sebagai guru yang tersabar dalam memberikan pemahaman karena dapat dibaca berulang-ulang sehingga pembaca menemukan kunci terbaik untuk menyelesaikan masalahnya. Dalam biblioterapi, buku merupakan media untuk memfasilitasi aktivitas terapi, membimbing diskusi, serta menunjukkan perkembangan berpikir individu sehingga biblioterapi menjadi langkah yang menyenangkan dalam membentuk perilaku positif.

\section{Serial Televisi sebagai Media Komunikasi}

Teks sastra dapat dikelompokkan menjadi tiga yaitu teks puitik, teks fiksi naratif, dan teks fiksi dramatik (Priyatni dan Nurhadi, 2017:121). Genre fiksi dramatik memiliki beragam jenis di antaranya adalah film, sinetron, teater, drama modern, dan drama tradisional. Teksteks tersebut memiliki fungsi penting yaitu unsur hiburan/kesenangan. Dalam teks dramatik, kekuatan teks-teks tersebut tidak perlu dipertanyakan lagi. Banyak orang rela berjam-jam menyaksikan film dan seni pertunjukan karena unsur hiburan dan mencari kesenangan dengan menikmati tiap adegannya. Kekuatan dari teks dramatik antara lain materi dan nilai cerita, pemainnya, penataan panggung, musik, dan sebagainya. Materi dan nilai cerita yang terkandung dalam filmdan sinetron (termasuk serial televisi) inilah yang menjadi pertimbangan dalam pemilihan media pembelajaran.Karena seiring dengan kebangkitan film muncul pula film-film yang mengumbar seks, kriminal, dan kekerasan. Hal ini patut diperhatikan mengingat film memiliki kekuatan dan kemampuan menjangkau banyak segmen sosial yang lantas membuat para ahli meyakini bahwa film memiliki potensi untuk memengaruhi khalayaknya (Sobur, 2009:127).

Untuk serial televisi sendiri, pemrograman jaringan dimulai dalam skala besar di akhir 1940-an awal 1950-an (Danesi, 2011:275). Pertama-tama, televisi sekadar mengadaptasi jenis acara radio menjadi program sitkom. Selanjutnya muncul beberapa drama yang lebih serius dan drama berseri yang ternyata jauh lebih populer karena format dan gaya ceritanya menarik bagi banyak orang. Genre dari serial televisi tersebut juga makin lama makin beragam seperti penegak hukum (polisi, pengacara, dan detektif), kaum pionir (pendatang) di Amerika, perang, mata-mata, fiksi ilmiah serta yang juga amat populer terutama di kalangan penonton wanita yaitu opera sabun yang bercerita tentang berbagai aspek hubungan manusia.

Kini, makna film bukan lagi sekadar refleksi masyarakat (sekadar "memindah" realitas ke layar tanpa mengubahnya), melainkan sebagai representasi dari realitas tersebut yaitu membentuk dan "menghadirkan kembali" realitas berdasarkan kode-kode, konvensikonvensi, dan ideologi dari kebudayaannya (Turner, dalam Sobur, 2009:128). Representasi pada dasarnya ingin melihat bagaimana seseorang, kelompok, tindakan, dan kegiatan ditampilkan dalam teks (Fairclough, dalam Eriyanto, 2006:290). Representasi tersebut dilihat dari bagaimana seseorang, kelompok, dan gagasan ditampilkan dalam anak kalimat dan gabungan atau rangkaian antar anak kalimat. 


\section{METODOLOGI PENELITIAN}

Penelitian ini merupakan penelitian kualitatif dengan menggunakan metode analisis semiotika. Penelitian kualitatif pada umumnya dirancang untuk memberikan pengalaman senyatanya danmenangkap makna sebagaimana yang tercipta di lapangan penelitianmelalui interaksi langsung antara peneliti dengan yang diteliti. Afrizal (2015:13) mendefinisikan metode penelitian kualitatif sebagai metode penelitian ilmu- ilmu sosial yang mengumpulkan dan menganalisis data berupa kata-kata (lisan maupun tulisan) dan perbuatan-perbuatan manusia serta peneliti tidak berusaha menghitung atau mengkuantifikasikan data kualitatif yang telah diperoleh dan dengan demikian tidak menganalisis angka-angka.

Sedangkan metode yang digunakan dalam penelitian ini adalah analisis semiotika. Secara terminologis, semiotika dapat diidentifikasikan sebagai ilmu yang mempelajari sederetan luas objek-objek, peristiwa-peristiwa, seluruh kebudayaan sebagai tanda (Wibowo, 2013:7). Semiotika digunakan sebagai pendekatan untuk menganalisis media dengan asumsi bahwa media itu sendiri dikomunikasikan melalui seperangkat tanda. Tugas pokok semiotika adalah mengidentifikasi, mendokumentasikan, dan mengklasifikasi jenis-jenis utama tanda dan cara penggunaannya dalam aktivitas yang bersifat representatif.

Metodesemiotika meliputi studi tanda-tanda sinkronik maupun diakronik - istilah yang diperkenalkan oleh Saussure (Danesi, 2011:12). Analisissemiotik bersifat paradigmatik, dalam arti berupaya menemukan maknatermasuk dari hal-hal yang tersembunyi di balik sebuah teks.

\section{Objek Penelitian}

Objek dalam penelitian ini adalah serial televisi When Calls The Heart yang terdiri dari 6 musim (2014-2019) dan 60 episode. Namun peneliti akan berfokus hanya pada 1 episode yaitu musim ke-3 episode khusus "New Year's Wish" (2015). Episode tersebut dipilih atas dasar kesesuaian teks-teks yang dominan padapenggambaran biblioterapi.

\section{Unit Analisis}

Unit analisis dalam penelitian ini adalah teks-teks berupa narasi dan gambar yang berkaitan dengan praktik biblioterapi.

\section{Teknik Pengumpulan Data}

Dalam penelitian ini, data didapat dan dikumpulkan dengan cara:

1. Pengumpulan Data Primer

Data primer dalam penelitian ini diperoleh dengan menontonfilm secara keseluruhan kemudian menganalisis ataumenelaah teks-teks film tersebut melalui gambar-gambar visual dan narasi yang dapat merepresentasikan biblioterapi. Representasi sendiri dapat didefinisikan lebih jelasnya sebagai penggunaan tanda (gambar, bunyi, dan lain-lain) untuk menghubungkan, menggambarkan, memotret, atau mereproduksi sesuatu yang dilihat, diindera, dibayangkan, atau dirasakan dalam bentuk fisik tertentu (Danesi, 2011:20).

Subjek dalam penelitian ini adalah tokoh-tokoh utama maupun tokoh tambahan yang merujuk pada teks-teks yang direpresentasikan oleh karakter guru dan murid yang terlibat dalam biblioterapi.Selanjutnya akan dipilih teks-teksfilm yang menampilkan praktik-praktik 
biblioterapi. Data yang diperoleh melalui teks-teks tersebut digunakan sebagai datapokok atau data utama karena cuplikan adegan dalam teks-teks visual bermakna inilah yang menjadi unit analisis dalam penelitian.

\section{Pengumpulan Data Sekunder}

Pengumpulan data sekunder didapatkan melalui studipustaka. Peneliti melakukan penelusuran data yang berasal daribuku dan sumber-sumber dari internet yang mendukung. Studi kepustakaan disaring agar relevan denganfenomena yang diteliti sehingga berguna dalam menambah, menguatkan, serta memperjelas analisis.

\section{HASIL DAN PEMBAHASAN}

Berikut ini akan diuraikan hasil temuan data dari teks-teks visual yang ditampilkan dalam serial televisi When Calls The Heart, yang kemudian dianalisis dengan metode analisis semiotika untuk menjawab fokus masalah yang ditetapkan. Kita tahu bahwa saat ini menonton film termasuk serial televisi bukan hanya dipandang sebagai aktivitas yang bersifat rekreatif atau sebagai sarana hiburan saja, melainkan juga sebagai fenomena gaya hidup masyarakat sehingga menonton film dapat pula disebut sebagai aktivitas budaya. Karena seperti halnya dengan buku dan lagu, film juga merupakan produk budaya populer.

Film dan serial televisi juga terus berkembang seiring dengan berkembangnya industri pertelevisian. Dalam perkembangan tersebut, televisi telah menciptakan sebentuk kemelekan huruf yang memberi informasi dan melibatkan lebih banyak orang dibanding yang dapat dilakukan bentuk kemelekan huruf lainnya dalam sejarah manusia. Seperti halnya bentuk-bentuk representasi lainnya dari teks agama hingga novel, televisi berdampak besar atas kebudayaan dan pada individu yang hidup di dalamnya. Televisi menjadi instrumen penting dalam menghadirkan perubahan yang signifikan dalam masyarakat. Hingga saat ini orang masih terus menangkap sebagian besar informasi, stimulasi intelektual, dan hiburan mereka dari televisi. Di luar bentuk dan isinya, televisi selalu menjadi media yang kuat karena kemampuannya menyatukan populasi nasional yang sangat luas.

Dalam hal penyatuan populasi nasional ini, salah satu stasiun televisi di Amerika Serikat yaitu Hallmark Channel merupakan fenomena tersendiri. Stasiun milik Crown Media Holdings, Inc. ini berdiri sejak 5 Agustus 2001 di Studio City, California. Dengan slogan "The Heart of $T V$ ”, Hallmark Channel menayangkan program-program bertemakan keluarga termasuk film televisi dan serial maupun miniseri, serta gaya hidup.

Salah satu serial unggulan Hallmark Channel yang digemari masyarakat Amerika terutama kaum perempuan adalah When Calls The Heart. Serial ini ditayangkan di Amerika Serikat dan Kanada sejak 11 Januari 2014 (musim pertama) dan terakhir tayang pada 2 Juni 2019 (musim ke-6). Serial ini masih akan dilanjutkan untuk musim ke-7 yang akan ditayangkan pada 2020 mendatang. Dalam setiap penayangannya, para penggemar yang menamakan diri mereka "Hearties" ini akan mengadakan obrolan langsung dengan para pemainnya melalui media sosial Twitter. Di samping itu, mereka juga mengadakan acara "Hearties Family Reunion" setahun sekali di Vancouver, Kanada yang merupakan lokasi syuting When Calls The Heart.

Selain karena mengusung tema-tema yang sederhana dan relatif aman bagi semua 
umur karena tidak mengandung unsur kekerasan, seks bebas, LGBT, dan obat- obatan terlarang, baik film maupun serial televisi dari Hallmark Channel juga dikenal banyak mengandung pesan literasi, demikian pula dengan When Calls The Heart. Salah satunya adalah representasi biblioterapi.

Selama berabad-abad, buku telah menjadi "terapis" bagi banyak orang. Melalui buku, pembaca dapat memasuki peran baru; mereka seolah-olah mengalami sendiri contoh-contoh kehidupan dan gaya hidup. Buku fiksi dapat memberikan klien model- model yang dapat membantu mengatasi masalah yang dihadapinya, sedangkan buku nonfiksi dapat memberikan klien pengaruh nyata dan saran yang membantunya mengatasi masalah yang dihadapinya. Hal ini direpresentasikan dalam When Calls The Heart musim ke-3 episode “The New Year's Wish" yang ditayangkan pertama kali pada 26 Desember 2015. Herlina juga mengemukakan bahwa lebih dari beberapa tahun lalu biblioterapi telah digunakan oleh berbagai profesional pemberi bantuan seperti konselor, psikolog, psikiater, dan pendidik (guru) yang dalam hal ini diwakili oleh Elizabeth Thatcher (menjadi Elizabeth Thornton pada musim ke-5 setelah menikah), tokoh utama dalam When Calls The Heart.

\section{Tahapan-Tahapan Biblioterapi}

Pardeck dan Pardeck (dalam Herlina, 2013:110) menyatakan bahwa biblioterapi merupakan proses yang mencakup tahap-tahap sebagai berikut:

1. Kesiapan

Kesiapan anak merupakan faktor penting yang harus dipertimbangkan. Salah satu syaratnya adalah telah dilakukan eksplorasi awal dari permasalahan yang dialami. Ini direpresentasikan dalam adegan antara Miss Elizabeth Thatcher (ET) (guru) dengan Laura Campbell (LC) (murid yang bermasalah) dan Mr Campbell (Mr C) (ayah Laura) sebagai berikut:

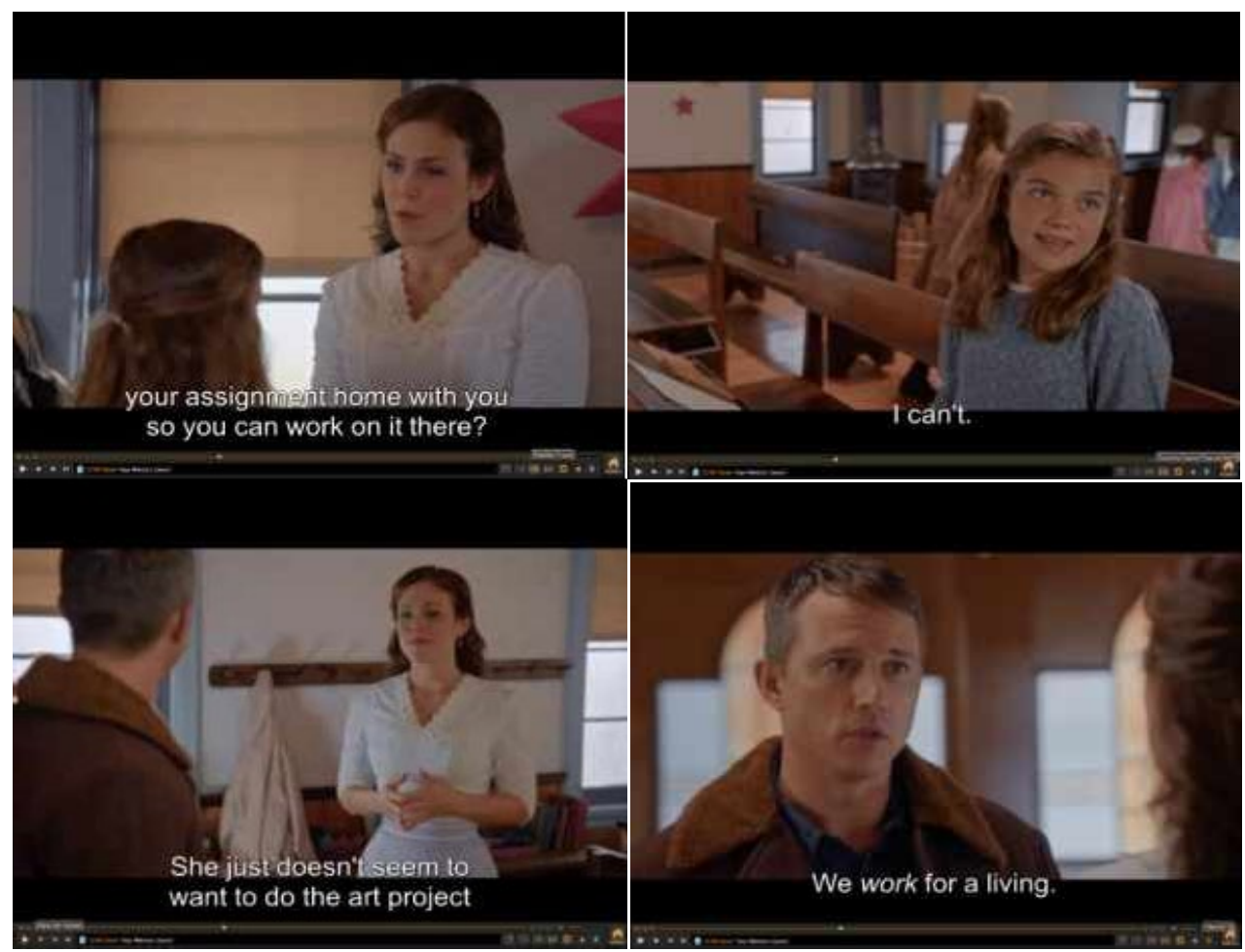

Gambar 1. Eksplorasi permasalahan sebelum menentukan kesiapan anak 
ET : Laura? Why don't you take your assignment home with you so you can work on it there? (Laura? Mengapa tidak kamu bawa tugasmu pulang supaya bisa kamu kerjakan di rumah?)

LC : I can't. (Saya tidak bisa)

ET : Mr Campbell? May I speak with you for a moment, about Laura? (Mr Campbell? Boleh saya bicara sebentar, tentang Laura?)

Mr C : What about her? (Ada apa dengannya?)

ET : Oh, no, no, it's all right. She just doesn't seem to want to do the art project I assigned in class today. (Oh, tidak, tidak, tidak apa-apa. Hanya saja dia sepertinya tidak mau mengerjakan proyek seni yang saya tugaskan di kelas hari ini)

Mr C : I send my daughter to school to learn. (Saya mengirim anak saya ke sekolah untuk belajar)

ET : Well, there's more to learning than just reading and writing. (Ada banyak cara belajar, bukan hanya membaca dan menulis)

Mr C : Pardon me for speaking plainly, Miss Thatcher, but you don't understand what life is like for people like us. We work for a living. (Maaf jika saya bicara terus terang, Miss Thatcher, tapi Anda tidak mengerti seperti apa hidup bagi orang-orang seperti kami. Kami bekerja untuk hidup)

ET : Yes, but... being creative is part of "work" for children. (Ya, tapi... jadi kreatif juga adalah bagian dari "bekerja" bagi anak).

(When Calls The Heart: New Year's Wish, 2015)

Dari adegan tersebut dapat diinterpretasikan bahwa Miss Thatcher mencoba menggali apa yang sedang terjadi pada Laura yang saat jam pulang sekolah ternyata meninggalkan lembar pekerjaan rumah yang ditugaskannya di atas bangku sekolah. Miss Thatcher pertama-tama menanyai Laura mengapa dia tidak membawa pekerjaan rumahnya, dan Laura menjawab dia tidak dapat mengerjakannya di rumah. Lebih lanjut Miss Thatcher menanyai Mr Campbell tentang pekerjaan rumah itu, dan Mr Campbell menjelaskan bahwa dengan kondisi keluarganya saat ini, mereka harus "bekerja" untuk tetap hidup, terutama setelah ibu Laura meninggal. "Bekerja" di sini yang dimaksud adalah mengerjakan "urusan rumah tangga" ketika di rumah, dan belajar hanya dilakukan di sekolah. Dengan pemahaman seperti itu, wajar bila Laura merasa tidak bisa mengerjakan proyek keseniannyadi rumah. Padahal dalam pemahaman Miss Thatcher sebagai guru, belajar bukan hanya tentang membaca dan menulis. Ada banyak hal yang dapat dilakukan untuk belajar dan melatih kreativitas anak sebagai bagian dari "bekerja" itu sendiri.

\section{Seleksi Buku}

Dalam menyeleksi buku yang akan digunakan sebagai alat treatment, hal-hal yang harus diperhatikan terapis di antaranya adalah masalah yang sedang dihadapi anak, tingkat keparahan gejala, kemampuan kognitif, minat dan tingkat kemampuan membaca, serta kemampuan fisik. Bacaan yang dipilih harus sejalan dengan masalah yang dihadapi anak.Referensi judul buku yang baik dibaca anak memang sangat relatif. Semua buku dan bacaan memiliki kelebihan dan kekurangannya masing-masing untuk setiap anak. Hal terbaik yang dapat dilakukan adalah menyesuaikan tahap perkembangan anak dengan jenis buku yang ada, di mana referensi buku untuk usia 6-12 adalah illustrated chapter book. Illustrated chapter book adalah buku cerita yang teksnya sudah banyak, ceritanya mulai panjang (sudah dibagi dalam bab), tetapi masih ada ilustrasinya (Berk, dalam Agustina, 2017:132).

Pardeck (dalam Herlina, 2013:90) mengemukakan bahwa biblioterapi bisa jadi lebih kompleks daripada terapi lain karena seseorang harus terampil baik dalam memilih literatur yang sejalan dengan masalah yang dihadapi klien maupun mengetahui bagaimana menggunakan literatur tersebut sebagai media terapeutik. 


\section{Memperkenalkan Buku}

Terapis harus benar-benar mengenal dengan baik isi dari buku yang dipilihnya sebelum dikenalkan kepada anak. Adapun tahap seleksi dan memperkenalkan buku direpresentasikan dalam adegan sebagai berikut:

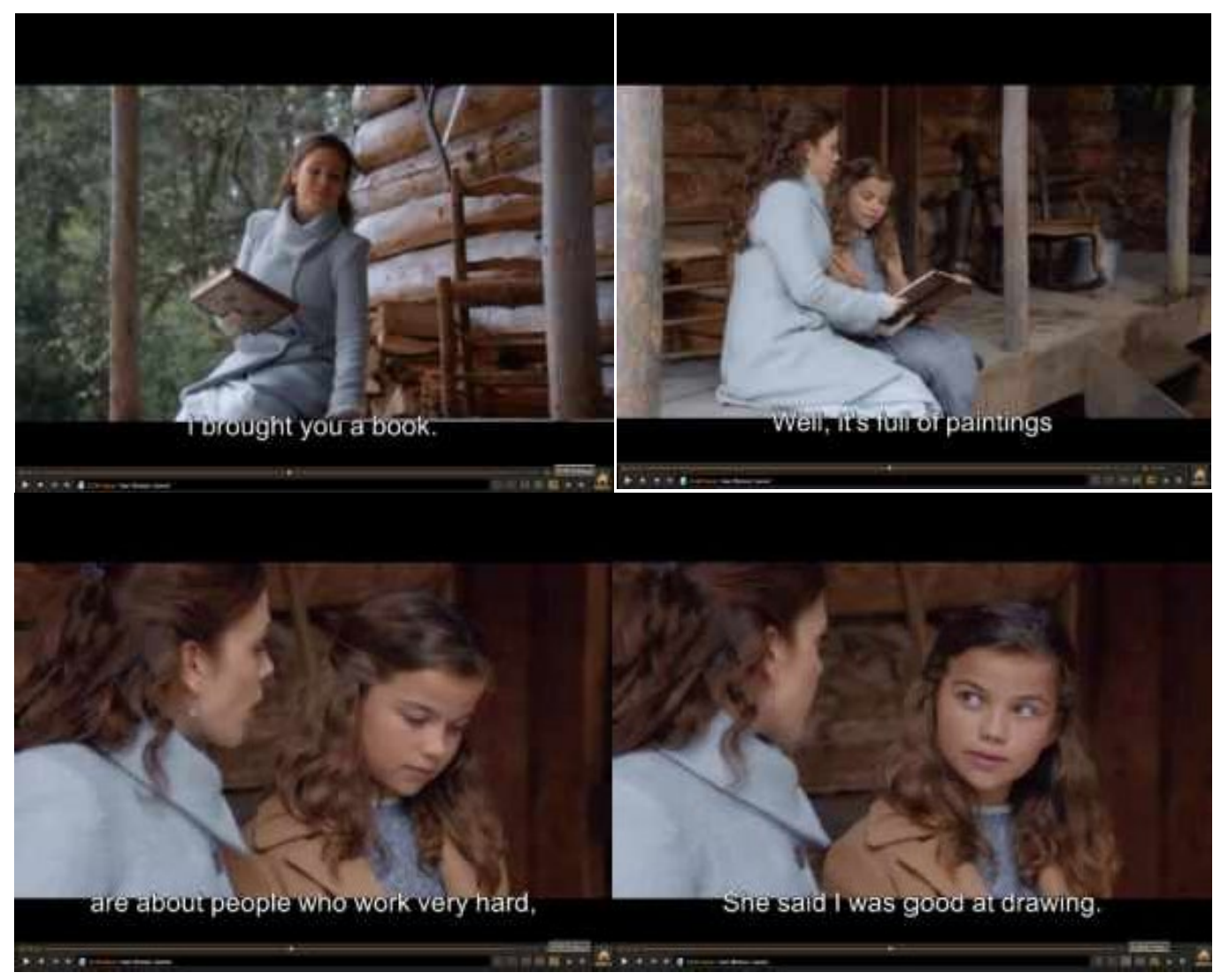

Gambar 2. Seleksi buku dan memperkenalkannya

ET : I brought you a book. I thought we might look at it together. (Ibu membawakanmu buku. Ibu pikir kita bisa melihatnya bersama)

LC : What kind of book? (Buku apa?)

ET : Well, it's full of paintings by famous artists, like Harvey Dunn. He grew up on the frontier just like you, and a lot of his paintings are about people who work very hard, just like you and your Dad.(Well, di buku ini banyak lukisan dari seniman terkenal, seperti Harvey Dunn. Dia tumbuh di daerah perbatasan seperti kamu, dan banyak lukisannya tentang orang-orang yang bekerja keras, seperti kamu dan ayahmu)

LC : This lady looks like My Mom. (Wanita ini mirip ibu saya)

ET : Did your Mom have red hair? (Apa ibumu berambut merah?)

LC : Yeah. She said I was good at drawing. (Ya. Ibu bilang saya pandai menggambar)

ET : I'm sure she wouldn't want you to be sad all the time, Laura. She wouldn't want your Dad to be sad, either. (Ibu yakin dia tidak ingin kamu sedih terus menerus, Laura. Dia juga tidak menginginkan ayahmu bersedih)

LC : Can I keep this? (Bolehkah saya membawanya?)

ET : I was hoping you'd want to. Here, let me show you another. (Ibu berharap begitu. Sini, biar Ibu tunjukkan gambar yang lain)

LC : That's nice. (Ibu baik) (When Calls The Heart: New Year's Wish, 2015)

Dari adegan di atas dapat diinterpretasikan bahwa Miss Thatcher telah melakukan seleksi terhadap buku-buku yang dimilikinya dan memilih sebuah buku yang dianggap 
paling cocok dengan usia dan permasalahan yang dihadapi Laura. Buku itu lalu dibawa ke rumah Laura untuk diperlihatkan kepadanya. Tidak disebutkan judul buku yang dipilih Miss Thatcher, tetapi dari percakapan dan gambaran buku sekilas di atas kita ketahui bahwa di dalam buku itu terdapat banyak gambar ilustrasi dari seniman-seniman terkenal salah satunyaHarvey Dunn. Harvey Dunn (7 Maret 1884 - 29 Oktober 1952) merupakan seorang ilustrator dan guru kesenian yang lahir dan besar di daerah padang rumput dekat Manchester, South Dakota, Amerika Serikat. ${ }^{4}$ Meskipun kemudian merantau hingga ke Tenafly, New Jersey setelah Perang Dunia Idan menjadi ilustrator terkenal, tetapi dia tidak pernah lupa mengunjungi kampung halamannya untuk menggambar.

Gambaran tersebut oleh Miss Thatcher dianggap sesuai dengan permasalahan Laura, di mana anak itu sebenarnya memiliki bakat untuk menggambar akan tetapi merasa tidak memiliki cukup waktu untuk mengembangkan bakatnya karena kehidupan yang keras di daerah perbatasan. Memang di usia sekolah, keluarga masih akan menjadi tempat berkeluh kesah saat anak memiliki masalah. Namun begitu, tidak semua anak memiliki keluarga seperti harapannya yaitu keluarga yang utuh dan memberinya kebutuhan afektif. Dalam hal ini adalah karena sang ibu telah meninggal. Masalah- masalah dalam keluarga tersebut dapat memunculkan masalah perilaku pada anak seperti masalah akademik, kesulitan dalam menyesuaikan diri, merasa cemas dengan kondisi baru yang harus dihadapinya, masalah emosional, merasa tertekan, tidak percaya diri, masalah perilaku, serta mudah terpengaruh dengan pergaulan yang negatif (Hapsari, 2016:307).

Selanjutnya, dengan buku yang telah dipilihnya Miss Thatcher mencoba mengajak Laura bercermin pada kisah hidup dan karya-karya Harvey Dunn serta seniman lainnya, bahwa kehidupan keras sebagai kaum pionir di perbatasan, pedalaman, pertanian, maupun padang rumput tidak menghalangi mereka untuk berkarya sampai akhirnya bisa meraih kesuksesan. Miss Thatcher juga meyakinkan Laura untuk tidak bersedih karena ibunya yang sejak lama telah menyadari bahwa anaknya pandai menggambar tentunya tidak menginginkannya juga ayahnya bersedih. Laura pun merasa tertarik dan memutuskan meminjam buku itu untuk dibaca lagi.

\section{Strategi Tindak Lanjut}

Kegiatan membaca buku harus disertai dengan diskusi dan/atau konseling. Dengan bimbingan dari terapis, anak terbantu untuk mengidentifikasikan diri dengan karakter buku yang memiliki masalah yang mirip dengan masalah dirinya. Melalui proses ini, anak mulai melihat bagaimana karakter dalam buku ini mengatasi masalahnya dan kemudian mengenali pemecahannya (Pardeck, dalam Herlina, 2013:114). Kegiatan diskusi dalam biblioterapi direpresentasikan pada adegan berikut:

\footnotetext{
${ }^{4}$ https://www.sdstate.edu/south-dakota-art-museum/harvey-dunns-biography
} 


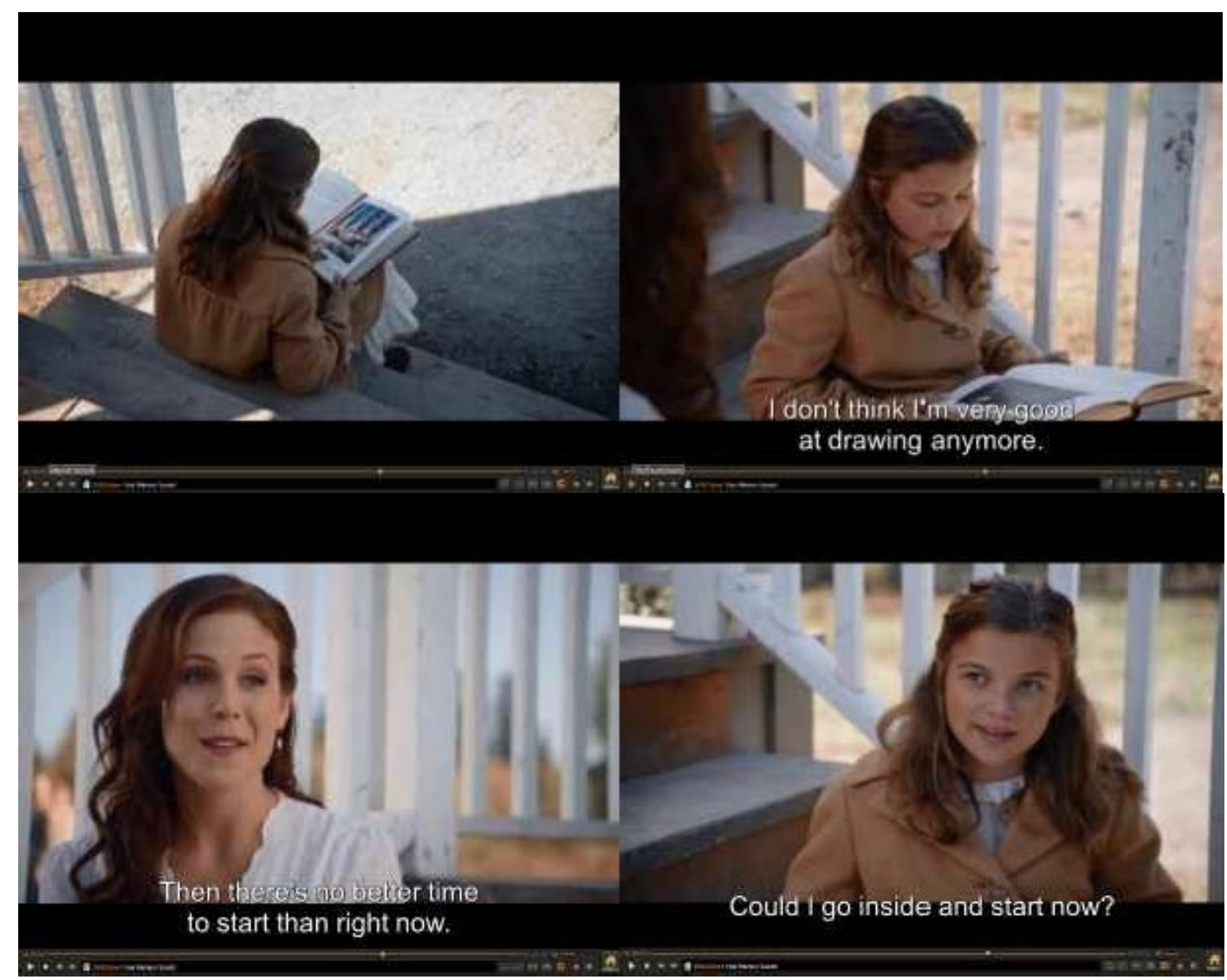

Gambar 3. Strategi tindak lanjut (diskusi)

ET : So... what do you think? (Jadi... bagaimana menurutmu?)

LC : They're so pretty. But... (Gambar-gambar ini sangat indah. Tapi...)

ET : But what? (Tapi apa?)

LC : I don't think I'm very good at drawing anymore. (Sepertinya saya tidak lagi terlalu pandai menggambar)

ET : Well, you won't know until you try. (Well, kamu tidak akan tahu bila tidak mencobanya)

LC : I haven't done it in so long. (Sudah lama saya tidak melakukannya)

ET : There's no better time to start than right now. There's still time to make something for the New Year's contest. And what do you have to lose? The worst that could happen you've wasted time. But, on the other hand, you could surprise yourself and have some fun. (Tidak ada waktu yang lebih baik untuk memulainya daripada sekarang. Masih ada waktu untuk membuat sesuatu untuk kontes Tahun Baru. Dan kamu akan kehilangan apa? Yang terburuk hanya kamu akan membuang waktu. Tapi selain itu kamu bisa mengejutkan dirimu sendiri dan bersenang-senang)

LC : Could I go inside and start right now? (Bolehkah saya masuk dan mulai sekarang juga?)

ET : I'll get you some paper. (Ibu akan mengambilkanmu kertas)

(When Calls The Heart: The New Year's Wish, 2015)

Dari adegan di atas dapat diinterpretasikan bahwa selama Laura membaca buku, Miss Thatcher berusaha melakukan diskusi dengannya pada saat jam istirahat sekolah. Dalam diskusi tersebut, Miss Thatcher mendorong dan memberi semangat agar Laura memulai untuk menggambar lagi karena masih ada cukup waktu untuk berpartisipasi dalam kontes kesenian Tahun Baru. Karena di masa usia sekolah seperti Laura, anak- anak memiliki beberapa karakteristik di antaranya adalah sebagai periode kritis dalam dorongan berprestasi dan sebagai usia kreatif, sehingga bila anak dibesarkan dengan label positif, diberi kebebasan untuk memilih apa yang ingin dilakukan, tidak terhalang oleh ejekan, cemoohan dan label 
negatif, anak akan mengerahkan tenaganya untuk melakukan kegiatan-kegiatan yang kreatif (Hurlock, dalam Hapsari, 2016:253).Meskipun pada awalnya sempat ragu-ragu, akhirnya Laura pun mulai percaya diri untuk segera memulai menggambar.

\section{Hasil yang Dicapai dalam Biblioterapi}

Setelah Perang Dunia II, penggunaan biblioterapi meluas dan saat ini digunakan dalam profesi "membantu" pada setiap kelompok usia dan populasi. Biblioterapi digunakan oleh konselor sekolah, pekerja sosial, perawat kesehatan, guru, dan pustakawan untuk mengatasi berbagai isu dan permasalahan yang dalam penelitian ini terjadi pada anak usia sekolah.Karena pada dasarnya tujuan akhir dari biblioterapi adalah memberikan solusi atas permasalahan. Hal ini direpresentasikan dalam adegan sebagai berikut. Dalam adegan ini ada tokoh tambahan yang berbicara yaitu Mrs Rosemary Coulter (RC) dan Walikota Mr Henry Gowen (HG).

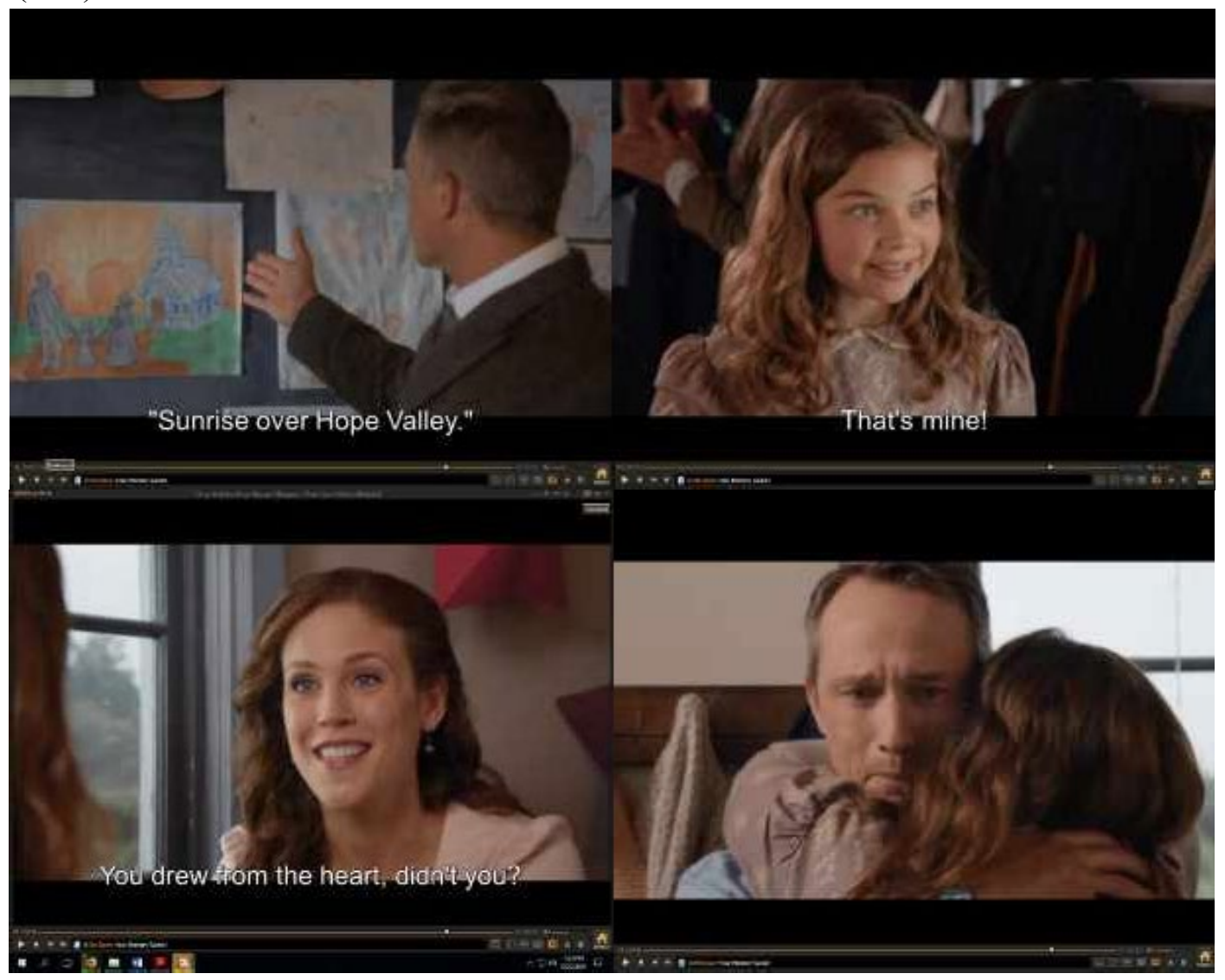

Gambar 4. Hasil dari biblioterapi

RC : And now, without further ado, Mayor Gowen, would you please announce the winner of our art contest? (Dan sekarang, tanpa basa basi, Walikota Gowen, silakan Anda umumkan pemenang kontes kesenian kita)

HG : The committee deliberated long and hard, "cause all of you did marvelous job, but the winner is... "Sunrise over Hope Valley." (Komite telah berunding cukup lama dan sulit, karena kamu semua luar biasa, tapi pemenangnya adalah... "Matahari Terbit di Atas Hope Valley")

LC : That's mine! (Itu milikku!)

ET : You drew from the heart, didn't you? (Kamu menggambar dengan hati, bukan?)

LC : Mama's our sunrise, Daddy. She wants us to be happy. (hugs) (Ibu adalah matahari terbit kita, Ayah. Dia ingin kita bahagia (berpelukan))

(When Calls The Heart: The New Year's Wish, 2015) 
Dalam adegan di atas dapat diinterpretasikan bahwa setelah melakukan biblioterapi bersama Miss Thatcher, Laura akhirnya berhasil mendapatkan pengaruh dari gambar-gambar maupun kisah hidup dari seniman dalam buku yang dibacanyauntuk mengatasi masalah yang dihadapinya yaitu masalah emosi (kesedihan) setelah kepergian ibunya serta masalah kepercayaan diri dalam berkarya. Dirinya kembali bersemangat menggambar untuk mengikuti kontes kesenian Tahun Baru. Usaha kerasnya ini ternyata berhasil, terbukti saat Walikota Gowen membacakan nama pemenang kontes kesenian tersebut, ternyata gambarnya yang diberi judul "Sunrise Over Hope Valley" terpilih menjadi pemenangnya. Laura bersama ayahnya pun dapat berbahagia kembali.

\section{PENUTUP}

\section{Simpulan}

Berdasarkan hasil penelitian yang telah dilakukan, dapat disimpulkan sebagai berikut:

1. Serial televisi When Calls The Heart mengandung pesan literasi khususnya yang terkait dengan representasi biblioterapi. Dalam berbagai adegan, nilai- nilai yang dianut dalam budaya disisipkan atau diformulasikan dalam sebuah teks secara tertulis dan visual, di mana teks-teks tersebut mengandung praktik biblioterapi. Sehingga yang perlu diperhatikan dalam hal ini adalah bagaimana film atau serial televisi sebagai media komunikasi massa dapat merepresentasikan biblioterapi pada masyarakat. Representasi seorang guru sebagai terapis digambarkan oleh Miss Elizabeth Thatcher, sedangkan klien (murid yang bermasalah) digambarkan oleh Laura Campbell.

2. Dalam praktik biblioterapinya, Miss Elizabeth Thatcher menyeleksi buku yang dianggap paling sesuai dengan permasalahan yang dihadapi Laura. Buku tersebut sesuai dengan tahap perkembangan usia Laura yaitu illustrated chapter book.

3. Dalam proses biblioterapi, Laura mengidentifikasikan diri dengan model yang terdapat dalam buku, dalam hal ini adalah Harvey Dunn, sang ilustrator serta gambar-gambar ilustrasi yang dibuat olehnya. Identifikasi dengan model yang positif merupakan tahap penting dalam perkembangan anak.

4. Selama mendampingi Laura membaca, Miss Thatcher juga mendiskusikan lebih lanjut tentang bakat Laura dalam menggambar serta memberi semangat karena Laura termasuk dalam anak usia kreatif sehingga perlu diberi dorongan untuk menggunakan bakatnya dengan sebaik-baiknya.

5. Praktik biblioterapi tersebut akhirnya berhasil, yang direpresentasikan dengan keberanian Laura untuk menggambar sebagai partisipasi dalam kontes kesenian Tahun Baru dan ternyata karyanya tersebut terpilih menjadi pemenang.

\section{Saran}

Berdasarkan praktik biblioterapi yang direpresentasikan oleh serial televisi When

Calls The Heart, peneliti memberikan saran-saran bahwa sebagai orangtua maupun pendidik termasuk pustakawan sudah selayaknya memperkaya pengetahuan akan metode biblioterapi sebagai cara untuk mengatasi permasalahan anak di dalam keluarga maupun lembaga. Untuk lingkup perpustakaan, biblioterapi dapat dipertimbangkan sebagai perluasan layanan pemustaka. Dalam hal ini orangtua maupun pendidik dan pustakawan harus terlebih dahulu 
mencintai buku dan menambah pengetahuan perbukuan untuk dapat menyeleksi buku-buku yang dapat digunakan dalam praktik biblioterapi. Selanjutnya di dalam memupuk budaya literasi pada umumnya, orangtua maupun pendidik dan pustakawan tidak harus mematikan televisi, akan tetapi lebih pada memilih program-program yang mengandung pesan-pesan tentang membaca dan menulis. Program-program tersebut bisa dijadikan tontonan dalam keluarga, sebagai sarana pembelajaran bagi para siswa di kelas, maupun sarana menonton bersama dalam kegiatan perpustakaan.

\section{DAFTAR PUSTAKA}

Afrizal. 2015. Metode Penelitian Kualitatif: Sebuah Upaya Mendukung Penggunaan Penelitian Kualitatif dalam Berbagai Disiplin Ilmu. Jakarta: Rajawali Pers.

Agustina, Susanti. 2017. Biblioterapi untuk Pengasuhan: Membangun Karakter Anak dengan Kisah. Jakarta: Noura Publishing.

Damaiwati, Elly. 2009. Karena Buku Senikmat Susu. Cet. 2. Yogyakarta: Afra Publishing.

Danesi, Marcel. 2011. Pesan, Tanda, dan Makna: Buku Teks Dasar Mengenai Semiotika dan Teori Komunikasi. Yogyakarta: Jalasutra.

Hapsari, Iriani Indri.(2016). Psikologi Perkembangan Anak. Jakarta: Indeks.

Herlina. 2013. Bibliotherapy: Mengatasi Masalah Anak dan Remaja Melalui Buku. Bandung: Pustaka Cendikia Utama.

http:/gln.kemdikbud.go.id/glnsite/wp-content/uploads/2018/04/gom_booklet2018.pdf Diakses 16 Desember 2018

http://www.heartieswcth.com/ Diakses 8 Oktober 2019.

. 2020. Harvey Dunn's Biography. Diakses di https://www.sdstate.edu/south-dakota-artmuseum/harvey-dunns-biography. Diakses 8 Oktober 2019.

http://www.thefutoncritic.com/ratings/2019/06/07/hallmark-channels-when-calls-the- heartwraps-up-season-six-as-number-2-scripted-series-on-cable-

243210/20190607hallmark01/ Diakses 8 Oktober 2019.

Gong, GolA. 2012. Jangan Matikan Televisi! Dalam Gol A. Gong \& Agus M. Irkham, Gempa Literasi: Dari Kampung Untuk Nusantara. Jakarta: Kepustakaan Populer Gramedia.

Leonhardt, Mary. 1997. Parents Who Love Reading, Kids Who Don't: Kiat Menumbuhkan Kegemaran Membaca pada Anak. Jakarta: Grasindo.

Priyatni, Endah Tri dan Nurhadi. 2017. Membaca Kritis dan Literasi Kritis. Tangerang: Tira Smart.

Sobur, Alex. 2009. Semiotika Komunikasi. Cet. 4. Bandung: Remaja Rosdakarya. Wibowo, Indiwan Seto Wahyu. 2013. Semiotika Komunikasi: Aplikasi Praktis Bagi Penelitian dan Skripsi Komunikasi. Jakarta: Mitra Wacana Media.

Widyastuti, Ana. 2017. Kiat Jitu Anak Gemar Baca Tulis. Jakarta: Elex Media Komputindo. 